\title{
Risk Factors of Protein Energy Malnutrition Deficiency among Children Under Five Years at Alruhal Camp-Kass Locality South Darfur State 2012 Sudan
}

\author{
Ahmed M Hussein* and Dawria Adam \\ Faculty of Public Health, Shendi University, Sudan \\ *Corresponding author: Ahmed M Hussein, Faculty of Public Health, Shendi University, P.O.Box 142, Sudan, Tel: +249-26-17-30-31; E-mail: \\ ahmedalhussein95@yahoo.com
}

Received date: September 25, 2015; Accepted date: December 02, 2015; Published date: December 07, 2015

Copyright: ( 2015 Hussein AM. This is an open-access article distributed under the terms of the Creative Commons Attribution License, which permits unrestricted use, distribution, and reproduction in any medium, provided the original author and source are credited.

\begin{abstract}
This cross-sectional descriptive study to measure the risk factors of protein energy malnutrition deficiency, this study designed to cover ( $n=384$ child), the study Shows that most affected children were those whose families income per month was less than 250 SDG, $(18.5 \%)$, The prevalence of malnutrition increase among children there is mothers illiterate $(13.4 \%)$, the study found that the male more affected $(12.5 \%)$ than female $(8.5 \%)$ and children there age (6-12 month most affected $7.7 \%)$.
\end{abstract}

Keywords: Factors; Malnutrition; Children; Kass

\section{Introduction}

Survey to assessment of protein energy malnutrition deficiency at south Darfur in February 2007, was covered both Nyala town and surrounding camps. The results of the study showed that the global acute malnutrition was found to be $18.9 \%$, while sever acute malnutrition was $1.0 \%$ [1].

The term malnutrition generally refers both to under nutrition and over nutrition, but in this guide we use the term to refer solely to a deficiency of nutrition, many factors can cause malnutrition, most of which relate to poor diet or severe and repeated infections, particularly in underprivileged populations [2].

Malnutrition is defined as a pathological state resulting from a relative or absolute deficiency or excess of one or more essential nutrients, this state being clinically manifested or detected only by biochemical, anthropometric or physiological tests, malnutrition is a hidden problem, it doesn't have obvious signs and victims are not aware. Acute and chronic malnutrition, vitamin A deficiency, iodine deficiency, iron deficiency anemia and zinc deficiency are manifestation of malnutrition [3].

The WHO estimates that by the year 2015 the incidence of malnutrition will have decreased to $17.6 \%$. Currently, 113.4 million children are affected by protein energy malnutrition "PEM" as measured by low weight for age, the majority of these cases living in developing countries with "70\%" of these children in Asia particularly south central region and "26\%" in Africa, more than half of young children in south Africa have "PEM" which is 6.5 time prevalence in the western hemisphere, In sub-Saharan Africa $30 \%$ of children have "PEM" [4].

The proportion of malnutrition among the admitted children in Gaafer Ibn Oaff Emergency Pediatric Hospital in sudan was (20.2\%), Males are more affected than the females $(29.1 \%)$. Socioeconomic status was $(36.1 \%)$ the age group (6-18) month are most affected
(65.7\%), Low educational level of mothers was (52.9\%) [5]. The nutritional status of 327 under-five children living in Mayoo displacement camp, Khartoum, Sudan, was assessed during MayAugust 2004.

Risk factors for protein-energy malnutrition (PEM) were also studied. According to WHO criteria, a total of 186 (56.1\%) children had malnutrition, of these 101 (30.1\%), 43 (13.1\%) and 42 (12.8\%) were mildly, moderately and severely malnourished respectively. According to welcome classification, the commonest type of malnutrition was found to be underweight (38.2\%), marasmus, kwashiorkor were detected in $(6.4 \%)$ and $(0.9 \%)$ respectively, there was no case of marasmic kwashiorkor in the studied population. Prevalence of vitamin "A" was $9.2 \%$ of which $0.9 \%$ had night blindness. Age, sex, lack of immunization, lack of breast-feeding, history of fever and history of diarrhoea were tested and were not found be risk factors for malnutrition in this group of children [6].

Chronic malnutrition by contrast is more closely associated with latent poverty, chronic food insecurity, poor feeding practices, and protracted health problems. The consequences of each condition are also quite different acute malnutrition is accompanied by a high risk of mortality; $14.6 \%$ of all child deaths are attributed to acute malnutrition and unless provided with appropriate treatment [7]. Under nutrition is not simply a result of food insecurity, many children in food-secure environments and from no poor families are underweight or stunted because of inappropriate infant feeding and care practices, poor access to health services, or poor sanitation. In many countries where malnutrition is widespread, food production is not the limiting factor except under famine conditions.

The most important factors are, first, inadequate knowledge about the benefits of exclusive breastfeeding and complementary feeding practices and the role of micronutrients and second, the lack of time women have available for appropriate infant care practices and their own care during pregnancy. Under nutrition's most damaging effect occurs during pregnancy and in the first two years of life, and the effects of this early damage on health [8]. 


\section{Associated risk factors for PEM}

Our review noted that PEM was more common among children from the lower social class $(69.4 \%)$ and those predominantly breast fed for three months or less $(48.6 \%)$ compared to exclusively breast fed children (18.9\%). The reason for this may not be unconnected to the fact that poor families have low purchasing power for adequate nutritious foods for their families. Illiteracy on the other hand, may influence feeding practices. The low rate of exclusive breast feeding noted in this review despite the Baby Friendly Initiatives is also very worrisome. Poverty and illiteracy as risk factors for PEM [9]. A management and prevention of malnutrition are based on the following strategies and adequate general ration for the whole community.

\section{Targeted (selective) feeding}

Supplementary feeding for moderately malnourished children. Therapeutic feeding to severely malnourished children. Mass (blanket) supplementary feeding to all children if excessive malnutrition rates Inclusion of other groups (e.g. pregnant and lactating women) where appropriate older persons and medically sick cases. Random untargeted food distribution, often initiated by well-meaning groups with little effective refugee experience, should be avoided [10].

It has been estimated that, in the 20 countries that are home to $80 \%$ of the world's stunted children, malnutrition was an underlying cause of $51 \%$ of diarrhoea deaths, $57 \%$ of malaria deaths, $52 \%$ of pneumonia deaths and $45 \%$ of measles deaths [11].

Complementary feeding is the introduction of foods other than breast milk or infant formula into the infant's diet, In fact the primary role of complementary feeding is neither to increase dietary diversity, nor to replace breastfeeding intake, Instead it used to make the child gradually become familiar with other foods than breast milk [12].

\section{Materials and Methods}

\section{Study area and population}

The study was carried out in Alruhal (nomads) Internal Displaced Population (IDP) camp at the suburbs of Kass locality (South Darfur, Sudan) in the period 2011-2012. Kass locality is $86 \mathrm{~km}$ from Nyala, the capital of South Darfur State. The camp has an estimated population of approximately 9860 people. Children under five were found to be 1972 . This is a community based cross sectional descriptive study. The objectives of the study are to measure the risk factors of protein energy malnutrition deficiency among children under five years.

\section{Study design}

Descriptive, cross-sectional community based study was conducted to the prevalence of protein energy malnutrition among children under five years kass locality.

\section{Sampling technique}

A sample was determined using the following statistical formula $\left(\mathrm{N}=\mathrm{z}^{2} \cdot \mathrm{p} \cdot \mathrm{q} / \mathrm{d}^{2}\right)$, systematic sampling and the sample size was (384) child, total population at camp e (9860), the percentage of children under five years are $20 \%$ of the population. The children under five years are (1972) child, number of $\mathrm{HH}=(1972)$ house, The number the Sampling interval, the number of households that should be visited is divided by the total number of households to the sample size, sample interval is (5), then determined the households randomly for the numbers of interval then applied the interval for nixes $\mathrm{HH}$, all children under five years (6-59) months, data was collected using a structured questionnaire directed to the mothers and anthropometric measurement tool was used, electronic scale high board, MUAC and the presence of oedema. The data was analyzed using micro-computer software programs (SPSS, Excel and Emergency Nutrition Assessment (ENA) to estimate the prevalence, weight for height $(<(-2) \mathrm{Z}$-score and/or oedema) and (SPSS version 16) to check the association among different variables.

\section{Results}

The study Shows that most affected children were those whose families income per month was less than 250 SDG, (18.5\%), The prevalence of malnutrition increase among children there is mothers illiterate $(13.4 \%)$, the study found that the male more affected $(12.5 \%)$ than female (8.5\%) and children there age (6-12 months most affected $7.7 \%$ ) (Tables 1 and 2).

\begin{tabular}{|l|l|l|l|l|l|l|}
\hline Malnutrition & \multicolumn{2}{|l|}{ Normal } & \multicolumn{2}{l|}{ Malnourished } & \multicolumn{2}{l|}{ Total } \\
\hline Monthly income & N & $\%$ & N & $\%$ & N & $\%$ \\
\hline Less than 250 SDG & 230 & 59.9 & 71 & 18.5 & 301 & 78.3 \\
\hline 250-299 SDG & 32 & 8.3 & 7 & 1.8 & 39 & 10.2 \\
\hline 300-349 SDG & 15 & 3.9 & 0 & 0 & 15 & 3.9 \\
\hline 350-399 SDG & 27 & 7 & 1 & 0.3 & 28 & 7.3 \\
\hline More than 450 SDG & 1 & 0.3 & 0 & 0 & 1 & 0.3 \\
\hline Total & 305 & 79.4 & 79 & 20.6 & 384 & 100 \\
\hline$X^{2}=10.936$, PV=0. 027, Significant & & & & \\
\hline
\end{tabular}

Table 1: The relation between family income and children affected with protein energy malnutrition deficiency, $\mathrm{N}=384$.

\begin{tabular}{|l|l|l|l|l|l|l|}
\hline Malnutrition & \multicolumn{2}{l|}{ Normal } & \multicolumn{2}{l|}{ Malnourished } & \multicolumn{2}{l|}{ Total } \\
\hline Educational & N & $\%$ & N & $\%$ & N & $\%$ \\
\hline Illiterate & 200 & 52 & 52 & 13.4 & 252 & 65.7 \\
\hline Khalwa & 86 & 22.4 & 18 & 4.7 & 104 & 27 \\
\hline Primary & 18 & 4.7 & 6 & 1.6 & 24 & 6.3 \\
\hline Secondary & 1 & 0.3 & 3 & 0.9 & 4 & 1 \\
\hline Total & 305 & 79.4 & 79 & 20.6 & 384 & 100 \\
\hline
\end{tabular}

$X^{2}=8.218, P V=0.042$, Significant

Table 2: The relation between mother educational level and children affected with protein energy malnutrition deficiency, $\mathrm{N}=384$.

\section{Discussion}

The malnutrition is strongly associated with mother low educational level of study population since it was higher among illiterates (13.5\%), this finding was statistically significant $\mathrm{X}^{2}=12.77,(\mathrm{P}=0.042)$ [2] in which they said that factor causing malnutrition were low birth, low 
education and low economic status [9]. The result of the study showed that children age group (6-12) months was more affected with malnutrition $(7.7 \%)$ than the other age groups, this finding was statistically significant (P 0.000) [5]. The age group (6-18) month are most affected (65.7\%), Low educational level of mothers was $(52.9 \%)$ and the results of the study showed that malnutrition was higher among families who have lower income of less than 250 SDG (18.5\%). This finding was statistically significant $(\mathrm{P}=0.027)[9]$ and the low rate of exclusive breast feeding noted in this review despite the Baby Friendly Initiatives is also very worrisome. Poverty and illiteracy as risk factors for PEM (Tables 1-5) (Figure 1).

\begin{tabular}{|l|l|l|l|l|l|l|}
\hline Malnutrition & \multicolumn{2}{l|}{ Normal } & \multicolumn{2}{l|}{ Malnourished } & \multicolumn{2}{l|}{ Total } \\
\hline Gender & N & $\%$ & N & $\%$ & N & $\%$ \\
\hline Male & 147 & 38.3 & 48 & 12.5 & 195 & 50.8 \\
\hline Female & 158 & 41.1 & 31 & 8.1 & 189 & 27 \\
\hline Total & 305 & 79.4 & 79 & 20.6 & 384 & 100 \\
\hline
\end{tabular}

$X^{2}=3.962, P V=0.047$, Significant

Table 3: The relation between Gender and protein energy malnutrition deficiency, $\mathrm{N}=384$.

\begin{tabular}{|l|l|l|l|l|l|l|}
\hline Malnutrition & \multicolumn{2}{l}{ Normal } & \multicolumn{2}{l|}{ Malnourished } & \multicolumn{2}{l|}{ Total } \\
\hline Age & $\mathbf{N}$ & $\%$ & $\mathbf{N}$ & $\%$ & $\mathbf{N}$ & $\%$ \\
\hline $6-12$ months & 27 & 7 & 30 & 7.7 & 57 & 15 \\
\hline $13-24$ months & 25 & 96 & 14 & 3.8 & 110 & 28.5 \\
\hline $25-37$ months & 20.6 & 79 & 10 & 2.7 & 89 & 23.1 \\
\hline $38-50$ months & 82 & 21.3 & 4.6 & 18 & 100 & 26.1 \\
\hline $51-59$ months & 21 & 5.5 & 7 & 1.9 & 28 & 7.3 \\
\hline Total & 305 & 79.4 & 79 & 20.6 & 384 & 100 \\
\hline
\end{tabular}

$X^{2}=1.014 E 2, P V=0.000$, Significant

Table 4: The relation between children age and protein energy malnutrition deficiency, $\mathrm{N}=384$.

\begin{tabular}{|l|l|l|l|l|l|l|}
\hline Malnutrition & \multicolumn{2}{l|}{ Normal } & \multicolumn{2}{l|}{ Malnourished } & \multicolumn{2}{l|}{ Total } \\
\hline $\begin{array}{l}\text { Diarrhoeal } \\
\text { disease }\end{array}$ & $\mathbf{N}$ & $\%$ & $\mathbf{N}$ & $\%$ & $\mathbf{N}$ & $\%$ \\
\hline Infected & 87 & 22.7 & 32 & 8.4 & 57 & 15 \\
\hline Not infected & 218 & 56.7 & 47 & 12.2 & 110 & 28.5 \\
\hline Total & 305 & 79.4 & 79 & 20.6 & 384 & 100 \\
\hline$X^{2}=4.212, P$ value=0.04, Significant & & & & \\
\hline
\end{tabular}

Table 5: Children having Diarrhoeal disease during the study relation to children affected with protein energy malnutrition deficiency, $\mathrm{N}=384$.

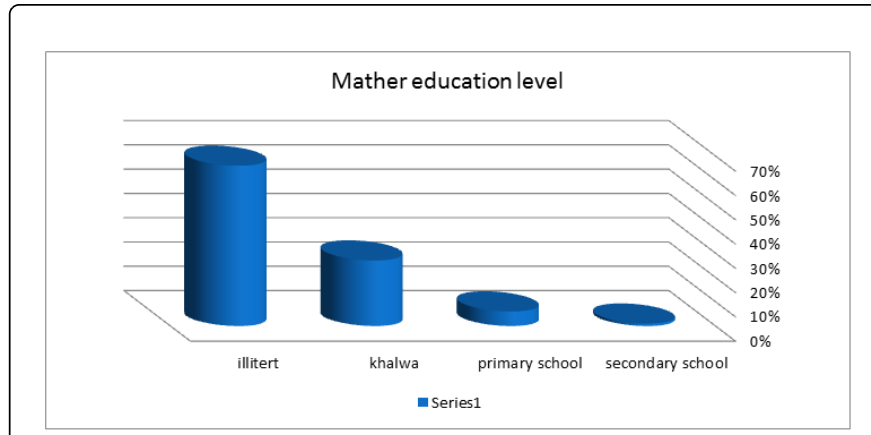

Figure 1: The Mather education level among children affected with protein energy malnutrition deficiency.

\section{Conclusion}

There are several factors due to protein energy malnutrition deficiency such as status of PEM was severe, PEM due to several factors behind it such as socioeconomic status low income, low education, diarrhoea, age and gender.

\section{Recommendations}

Nutrition education programs must be designed and directed to the mothers. Families with low income, can be helped through the productive family schemes, early detection and treatment children affected with diarrhoea, and the mother education program should be done.

\section{Acknowledgement}

The authors wish to deeply thank all regional and local health authorities in Kass locality for their work in nutrition programs, we also thank Dr. Abdelsafi gabaad, for his support this work.

\section{References}

1. UNICEF (2007) Assessing the Nutritional Status of Young Children, Network.

2. WHO (2005) malnutrition quantifying the health impact at national and local levels, Geneva, pp. 2.

3. Abuye AA, Urgaa KA (2010) Ethiopian Health and Nutrition Research Institute pp. 84.

4. World Health Organization (2002) Health situation in the South-East Asia Region, SEA/HS/222, WHO Regional Office for South-East Asia, New Delhi.

5. Alawia A (2009) Epidemiology of Malnutrition Among Children Under years admitted at Jafer Iben Owfe Pediatric Hospital, Research, Khartoum, pp.105.

6. Ahmed MH, Mamuon N (2005) Types and Risk Factors for Malnutrition in Khartuom (mayoo) Displaced Sudanese Children, Faculty of Medicine, University of Khartoum, pp. 84-88.

7. (2012) Institute for International Economic Policy, Food and Nutrition Technical Assistance Project, George Washington University, Washington, pp. 29.

8. World bank (2006) Repositioning Nutrition as Central to Development report Washington, Pp. 56.

9. Ubesie AC, Ibeziako NS, Ndiokwelu CI, Uzoka CM, Nwafor CA (2012) Under-five protein energy malnutrition admitted at the University of 
Citation: Hussein AM, Adam D (2015) Risk Factors of Protein Energy Malnutrition Deficiency among Children Under Five Years at Alruhal CampKass Locality South Darfur State 2012 Sudan. J Bacteriol Parasitol 6: 252. doi:10.4172/2155-9597.1000252

Page 4 of 4

Nigeria Teaching Hospital, Enugu: a 10 year retrospective review. Nutr J 11: 43 .

10. (2004) Roger Detels, Oxford Textbook of Public Health, Fourth Edition, New York, pp. 1731-1752.
11. (2012) Save children, life free from hanger, Tackling child malnutrition pp. 6.

12. Michael J, Elia M, Ljunquest O, Dow SJ (2005) Clinical Nutrition in Bound in India, Printed Replika Press Pulitd, Kudly, pp. 123. 